\title{
Development of Contents for Effective Computer Programming Education in Curriculum of Elementary Schools
}

\author{
Jong-soo Kim ${ }^{1}$,Soon-kak Kwon ${ }^{2, *}$
}

\begin{abstract}
In a variety of fields, highly developed technology is being combined to create a lot of value. In order to keep up with this global trend, the Ministry of Education, which is in charge of national education, continuously develops and applies content for creative education to textbooks. The continuous development of content for creative education is not only related to national interests, but also to the continued development of mankind. Today, the succession and development of human knowledge is in charge of the education system. Research into an effective educational system is necessary for effective succession of rapidly developing science and technology and building up technical personnel with such skills. In particular, the computer science field is faster in development than other scientific fields and has accumulated many technologies, indicating that it takes a lot of time and good teaching to foster talent that can effectively utilize the technology. In this paper, elementary school subjects were analyzed to achieve the purpose of cultivating talent in the field of computer science. In addition, we have investigated techniques related to computer programming learning not covered in elementary school subjects. So we developed content that students need to practice. Next, we taught the content to randomly selected elementary school students and assessed their educational effectiveness. As a result of training using the content we developed, 55.37\% increased academic performance.
\end{abstract}

Key Words: Content, Computer, Curriculum, Programming, Science and Technology.

\section{INTRODUCTION}

Technologies such as artificial intelligence, big data, robots and $5 \mathrm{G}$ information and communications are expanding day by day. There is a great deal of human wisdom accumulated by technological sophistication, and the systematic succession and development of this knowledge is paramount to the continued development of mankind [1-2].

A computer is a calculation tool that has a wide range of uses where cutting-edge technologies are quickly fused. As a member of modern society, to solve a given problem quickly and efficiently, the technology to program computers freely is useful and important [3].

However, in the current education system, after majoring in computer science, it often takes a long time to fully learn skills such as artificial intelligence and big data, and to have the ability to effectively solve given problems. Even in college and early industrial life, which can be very creative, one often fails to concentrate on creating value by using computers. This is because they need to learn additional programming skills required to implement an analysis or designed program.

In computer programming learning, it is a basic and important process to understand the characteristics and behavior of major electronic components. The current elementary school curriculum also includes some content on electrical circuits and electronic components. However, there is not much educational content on how to experiment or practice that can deepen the learning.

In this paper, in addition to the elementary school curriculum currently being conducted, we select some electromagnetic technologies that elementary school students can easily practice. Next, we develop some content so that those technologies can be reflected in computer program practice. Finally, we will use the content to educate students, and then study the effects of the training.

\footnotetext{
Manuscript received August 14, 2019; Revised September 01, 2019; Accepted September 12, 2019. (ID No. JMIS-19M-08-025) Corresponding Author (*): Soon-kak Kwon, Dept. of Computer Software Engineering, Dong-eui University, Busan, Korea, +82+51-890-1727, skkwon@deu.ac.kr.

${ }^{1}$ Software Convergence Center, Dong-eui University, Busan, Korea., seatree@ deu.ac.kr

${ }^{2}$ Dept. of Computer Software Engineering, Dong-eui University, Busan, Korea, skkwon@deu.ac.kr
} 


\section{ANALYSIS OF CURRICULUM IN ELEMENTARY SCHOOL}

In Korea, Efforts are being made by many educators to study efficient teaching methods and education systems and apply them to education sites. Representatively, a study on the comparison of education system in Korea and education system in other countries, In American elementary school project learning, a study on computer and internet utilization to improve thinking ability, a study on the development of IT convergence education program for middle and high school students, college students, and ordinary people, a study on the suggestion of developing the curriculum for computer engineering education in a 4year university using the NCS(National Competency Standards) system, after developing and educating algorithm contents for $5^{\text {th }}$ and $6^{\text {th }}$ graders, a study to find out if their problem-solving and logical thinking skills have improved, a study on the evaluation of computer program subjects and etc. there are many studies about it [4-9].

Also, in other countries, there is a lot of studies on how to teach English to elementary school students using scratch program, how to make educational content into software, how to develop educational content for students at high intellectual levels, and an efficient computer education for college students [10-16]. In this paper, we analyzed these prior studies to produce efficient computer programming education content for elementary school students.

According to OECD data, the computer and creativity capabilities of elementary, middle and high school students in Korea are among the lowest in OECD countries [17]. Because, from elementary, middle and high schools and universities in Korea to corporate and civil service examinations, all evaluation methods and their content focus only on the efficiency and fairness of selection of applicants. With regard to programming in elementary schools, the 'Information' class was strengthened to teach software in the revised 2015 curriculum. It reorganizes a part of the actual class of the $5^{\text {th }}$ and $6^{\text {th }}$ graders' classes into software-based education and allocates them for 17 hours.

We analyzed math, science and practical course textbooks related to computer programming among elementary school textbooks in 2019 to produce computer programming education content for elementary school students. Among the content covered by the subjects organized by each grade in elementary school, the semesters with content related to computer science are shown in Table 1.

Between 3-1 and 6-1, Science textbooks evenly introduce such fields as physics, geoscience, chemistry, biology, and so on. These fields of science can be taught in detail if students go to middle school.
Table 1. Elementary school computer science subject(Korea).

\begin{tabular}{|c|c|c|c|}
\hline Grade & Math & Science & $\begin{array}{c}\text { Practical } \\
\text { course }\end{array}$ \\
\hline $\mathbf{1}^{\text {th }}$ & $2-1$ & & \\
\hline $\mathbf{2}^{\text {th }}$ & $2-1$ & & \\
\hline $\mathbf{3}^{\text {th }}$ & $3-1$ & $3-1$ & \\
\hline $\mathbf{4}^{\text {th }}$ & $4-1$ & $4-1$ & \\
\hline $\mathbf{5}^{\text {th }}$ & $5-1$ & $5-1$ & 6 \\
\hline $\mathbf{6}^{\text {th }}$ & $6-1$ & $6-1$ & 6 \\
\hline
\end{tabular}

However, education on how to use computers to analyze and organize the results of scientific observations, especially programming that can foster creative thinking, appears for the first time in Practical course 6 which is composed of five and $6^{\text {th }}$ grade subjects. Its main content is "block-coding using entry" and "the status quo for the robot industry," which is composed only within only 17 hours. Most of all, 17 hours out of a total of 5,892 hours of mandatory classes for six years in elementary school are only $0.29 \%$ of the total.

\section{CONTENT DEVELOPMENT FOR CREATIVE COMPUTING EDUCATION}

\subsection{Elementary School Education and Advanced Science}

The development of high-capacity data storage and information-communication technologies makes it easy for even elementary school students to access videos introducing cutting-edge technology using the Internet. Having grasped its principles after mastered the art of the past one by one, teaching how to apply it is also one of good method of education. However, there is some disadvantages in such an approach that it may always lag behind in the latest technology, and that there may be a lack of time to develop new technology beyond the latest one. In order to improve national competitiveness, it is necessary to have an education system in place so that students who will enter the society can take advantage of advanced technology as early as possible.

In addition, in learning related to computer programming, it is necessary to systematically deepen the scientific technology related to computer hardware development, plan to identify the latest technological trends, and help students decide on their future activity. Computer programming education requires deep thinking and concentration, and also the training period is rather long. Therefore, software education for elementary school students with weak concentration and stamina needs to take into account the following points. 
(1) Interesting curriculum focused on practice

(2) A systematic computer programming training course for elementary, middle and high schools.

In this paper, the goal of developing computer education content for $5^{\text {th }}$ and $6^{\text {th }}$ graders in elementary school was set as follows.

- Training objectives: Technical training to program computers as intended, which are useful computational tools.

\subsection{Software training content for elementary school students}

We selected "Technologies to Understand the Characteristics of Computer Hardware" and "Technologies to Help Learn Computer Programming" for elementary school students. Table 2 shows a list of the content.

Table 1. Practical list for effective programming training.

\begin{tabular}{|l|l|}
\hline $\begin{array}{l}\text { Field of } \\
\text { study }\end{array}$ & Training Content \\
\hline Electricity & $\begin{array}{l}\text { - Direct current and alternating current } \\
\text { - Characteristics of electricity and magnetism }\end{array}$ \\
\hline $\begin{array}{l}\text { Electronic } \\
\text { circuit }\end{array}$ & $\begin{array}{l}\text { - How to use the breadboard? } \\
\text { - How to use circuit design program? } \\
\text { - Motor control circuit }\end{array}$ \\
\hline $\begin{array}{l}\text { - Solar energy } \\
\text { - Radio communication basic circuit }\end{array}$ \\
\hline $\begin{array}{l}\text { Entry } \\
\text { Mit }\end{array}$ & $\begin{array}{l}\text { - Block coding learning } \\
\text { - Circuit using ultrasonic sensors }\end{array}$ \\
\hline
\end{tabular}

Since April 2019, we have taught $5^{\text {th }}$ and $6^{\text {th }}$ graders in one randomly selected pilot school, and to evaluate the effectiveness. In view of the learning ability of elementary school students, we trained students to learn the principles through experience-oriented learning so that they could arouse interest in the field of study and help develop their own brains. A deep interpretation of the results is not covered here. Because students learn about it in middle school or high school.

\section{VERIFYING THE EFFECTIVENESS OF TRAINING CONTENT}

\subsection{Modification of Curriculum Objectives}

For $5^{\text {th }}$ and $6^{\text {th }}$ graders of elementary school, software programming education was conducted for a total of eight weeks every Thursday at the first and second classes, from April 18, 2019 to June 13, 2019. As the education is proceeded, the goals of the curriculum were revised as follows due to a lack of training time compared to the existing plans.

\section{-Education Objective: Creating a Remote Control Car using Micro: bit}

Based on the revised lecture plan, by analyzing the hardware built into Micro: bit, we produced the electrical circuit practical content for the students' education. In addition, educational content was developed to enable students to create programs that could control RC cars after acquiring basic knowledge of hardware.

Table 2. Modified lecture plan(Total of 8 weeks: 1st and 2nd classes every Thursday).

\begin{tabular}{|c|l|}
\hline Seq- & \multicolumn{1}{|c|}{ Lesson Plan } \\
\hline 1 & LED On circuit using the breadboard \\
\hline 2 & LED series and parallel circuits \\
\hline 3 & Characteristics and circuits of resistor \\
\hline 4 & Characteristics and circuits of capacitor \\
\hline 5 & Characteristics and circuits of semiconductor and diode \\
\hline 6 & Characteristics and circuits of transistor \\
\hline 7 & Physical computing using Micro: bit \\
\hline 8 & Physical computing using Micro: bit and RC car kit \\
\hline
\end{tabular}

To analyze the effectiveness of content, we used the "self-ability assessment" method that is one of the NCS curriculum development processes. It was carried out once before the beginning of the training course and once at the end of the course. As a technique for analyzing a survey, a chi-square test such as Formula 1 can be used to analyze differences in academic performance by grade or gender.

- Null hypothesis: A and B are independent of each other.

-Alternative hypothesis: The two variables A and B are not independent of each other. 


$$
x^{2}=\sum_{i=1}^{r} \sum_{j=1}^{c} \frac{(O-E)^{2}}{E}-x^{2}(r-1)(c-1)
$$

Where, $\mathrm{E}=\frac{n_{i} \times n_{j}}{n}$

Formula 1. Chi-square test.

Here, O: observed count, r: row count, c: column count, E: expected count, $\mathrm{n}$ : total sum, $\mathrm{n}_{\mathrm{i}}$ : row sum, $\mathrm{n}_{\mathrm{j}}$ : column sum In order to verify that the mean of academic performance by grade or gender is significant, a t-test, such as Formula 2, can be used.

$$
\mathrm{t}=\frac{\bar{X}_{1}-\bar{X}_{2}}{S E_{\bar{x} 1-\bar{x} 2}}
$$

Formula 2. t-test.

$\therefore$ Standard error of difference between two sample means

$$
E_{\bar{x} 1-\bar{x} 2}=\sqrt{\frac{S_{1}{ }^{2}}{n_{1}}+\frac{S_{2}{ }^{2}}{n_{2}}}
$$

Formula 3. Standard error.

Also, using the survey, we can analyze the correlation between pre-learning content and new content and use regression analysis to estimate the academic performance of the content to be learned in the future. In this paper, in order to find out the educational effect of the content we produced, the measured frequency was converted to numerical values and the results were shown.

\subsection{Analyze the results of "self-ability assessment"}

Total 22 students were participated in the first "selfability assessment" before the start of the training course at April 18, 2019(Thursday).

Table 2. Proportion of male and female students.

\begin{tabular}{|c|c|c|c|c|}
\hline Grade & Total & Male & Female & $\begin{array}{c}\text { Number of } \\
\text { students } \\
\text { in the second } \\
\text { trial }\end{array}$ \\
\hline $\mathbf{5}^{\text {th }}$ & 11 & 4 & 7 & 10 \\
\hline $\mathbf{6}^{\text {th }}$ & 11 & 5 & 6 & 9 \\
\hline total & $\mathbf{2 2}$ & $\mathbf{9}$ & $\mathbf{1 3}$ & $\mathbf{1 9}$ \\
\hline
\end{tabular}

Among these students, the number of students who participated in the second "self-ability assessment" is 10 in the $5^{\text {th }}$ grade and 9 in the $6^{\text {th }}$ grade. To measure students' academic performance, a three-point scale questionnaire was prepared as shown in Table 5 .

Among these students, the number of students who participated in the second "self-ability assessment" is 10 in the $5^{\text {th }}$ grade and 9 in the $6^{\text {th }}$ grade. To measure students' academic performance, a three-point scale questionnaire

\begin{tabular}{|c|c|c|c|c|}
\hline Seq. & Question & Well & $\begin{array}{c}\text { Some } \\
\text { what }\end{array}$ & $\begin{array}{c}\text { Not } \\
\text { at all }\end{array}$ \\
\hline 1 & $\begin{array}{l}\text { I know how direct current and alternating } \\
\text { current work. }\end{array}$ & & & \\
\hline 2 & $\begin{array}{l}\text { I know the direction of electrons flow in } \\
\text { an electronic circuit. }\end{array}$ & & & \\
\hline 3 & $\begin{array}{l}\text { I know the structure of the breadboard for } \\
\text { electronic circuit construction. }\end{array}$ & & & \\
\hline 4 & I know how LED works. & & & \\
\hline 5 & $\begin{array}{l}\text { I can light a LED using batteries, the } \\
\text { breadboard, the resistor and a LED. }\end{array}$ & & & \\
\hline 6 & $\begin{array}{l}\text { I know why resistor is needed in an } \\
\text { electronic circuit. }\end{array}$ & & & \\
\hline 7 & $\begin{array}{l}\text { I can turn on the light by connecting two } \\
\text { LEDs in parallel. }\end{array}$ & & & \\
\hline 8 & I know that a fever occurs in resistor. & & & \\
\hline 9 & I know the characteristics of resistor. & & & \\
\hline 10 & I know the characteristics of capacitor. & & & \\
\hline 11 & I know the characteristics of diode. & & & \\
\hline 12 & I know the characteristics of transistor. & & & \\
\hline 13 & $\begin{array}{l}\text { I know about sensor technology (light } \\
\text { sensor, ultrasonic sensor, etc.). }\end{array}$ & & & \\
\hline 14 & $\begin{array}{l}\text { I know the electronic components that } \\
\text { Micro: bit has. }\end{array}$ & & & \\
\hline 15 & $\begin{array}{l}\text { I understand the electronic components } \\
\text { that RC car has. }\end{array}$ & & & \\
\hline 16 & $\begin{array}{l}\text { I can block-coding the RC car motors to } \\
\text { move, using my Micro: bit and RC car kit. }\end{array}$ & & & \\
\hline 17 & $\begin{array}{l}\text { I can block-coding using Micro: bit and } \\
\text { RC car kit. }\end{array}$ & & & \\
\hline
\end{tabular}
was prepared as shown in Table 5 .

Table 3. "self-ability assessment" Questionnaire.

Using the questions as shown in the table above, the first and second "self-ability assessment" was completed. Figure 1 shows a graph of the individual academic performance. 


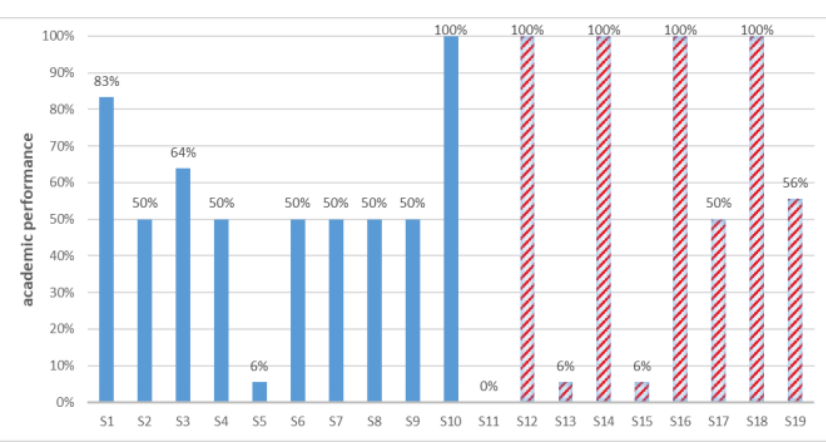

Fig. 1. Individual academic performance.

In the picture, the blue bars represent $5^{\text {th }}$ graders and the red bars drawn with a diagonal line represent $6^{\text {th }}$ graders. It is able to be seen that there are more students in the $6^{\text {th }}$ grade who have fully understood their education. The overall frequency shown in the "self-ability assessment", which was conducted for all $5^{\text {th }}$ and $6^{\text {th }}$ graders participated in the training course, is shown in Table 6.

Table 4. Academic performance of all participant.

\begin{tabular}{|c|c|c|c|c|c|c|c|c|}
\hline \multirow{2}{*}{$\begin{array}{c}\text { Question } \\
\text { number }\end{array}$} & \multicolumn{3}{|c|}{$\begin{array}{c}\text { Academic Achievement Rate: } \\
\text { Before the course begins(2019.04.18) }\end{array}$} & \multicolumn{3}{|c|}{$\begin{array}{c}\text { Academic Achievement Rate: } \\
\text { After the course begins(2019.06.13) }\end{array}$} \\
\cline { 2 - 9 } & Well & Somewhat & Not at all & $(\%)$ & Well & Somewhat & Not at all & (\%) \\
\hline 1 & 0 & 0 & 22 & $\mathbf{0 . 0 0 \%}$ & 7 & 8 & 4 & $\mathbf{5 8 \%}$ \\
\hline 2 & 0 & 1 & 21 & $\mathbf{2 . 2 7 \%}$ & 7 & 9 & 3 & $\mathbf{6 1 \%}$ \\
\hline 3 & 0 & 1 & 21 & $\mathbf{2 . 2 7 \%}$ & 8 & 7 & 4 & $\mathbf{6 1 \%}$ \\
\hline 4 & 0 & 0 & 22 & $\mathbf{0 . 0 0 \%}$ & 7 & 7 & 5 & $\mathbf{5 5 \%}$ \\
\hline 5 & 0 & 0 & 22 & $\mathbf{0 . 0 0 \%}$ & 9 & 7 & 3 & $\mathbf{6 6 \%}$ \\
\hline 6 & 0 & 0 & 22 & $\mathbf{0 . 0 0 \%}$ & 6 & 9 & 4 & $\mathbf{5 5 \%}$ \\
\hline 7 & 0 & 0 & 22 & $\mathbf{0 . 0 0 \%}$ & 8 & 9 & 2 & $\mathbf{6 6 \%}$ \\
\hline 8 & 0 & 0 & 22 & $\mathbf{0 . 0 0 \%}$ & 6 & 8 & 5 & $\mathbf{5 3 \%}$ \\
\hline 9 & 0 & 0 & 22 & $\mathbf{0 . 0 0 \%}$ & 5 & 10 & 4 & $\mathbf{5 3 \%}$ \\
\hline 10 & 0 & 0 & 22 & $\mathbf{0 . 0 0 \%}$ & 5 & 10 & 4 & $\mathbf{5 3 \%}$ \\
\hline 11 & 0 & 0 & 22 & $\mathbf{0 . 0 0 \%}$ & 6 & 8 & 5 & $\mathbf{5 3 \%}$ \\
\hline 12 & 0 & 0 & 22 & $\mathbf{0 . 0 0 \%}$ & 6 & 8 & 5 & $\mathbf{5 3 \%}$ \\
\hline 13 & 0 & 0 & 22 & $\mathbf{0 . 0 0 \%}$ & 5 & 10 & 4 & $\mathbf{5 3 \%}$ \\
\hline 14 & 0 & 0 & 22 & $\mathbf{0 . 0 0 \%}$ & 6 & 9 & 4 & $\mathbf{5 5 \%}$ \\
\hline 15 & 0 & 0 & 22 & $\mathbf{0 . 0 0 \%}$ & 6 & 9 & 4 & $\mathbf{5 5 \%}$ \\
\hline 16 & 0 & 0 & 22 & $\mathbf{0 . 0 0 \%}$ & 6 & 9 & 4 & $\mathbf{5 5 \%}$ \\
\hline 17 & 0 & 0 & 22 & $\mathbf{0 . 0 0 \%}$ & 6 & 9 & 4 & $\mathbf{5 5 \%}$ \\
\hline & \multicolumn{3}{|c|}{ Overall mean } & $\mathbf{0 . 2 7 \%}$ & \multicolumn{2}{|c|}{ Overall mean } & $\mathbf{5 6 \%}$ \\
\hline
\end{tabular}

Before starting our course, almost all of the students were not familiar with the content we had prepared, so the overall academic performance rate was low at $0.27 \%$. In the second self-ability assessment results conducted after completing the course, students' academic performance averaged $56 \%$ with $55.73 \%$ improvement. To analyze the differences in academic performance in each grade, the results of the "self-ability assessment" according to the academic performance of $5^{\text {th }}$ and $6^{\text {th }}$ graders are shown in Table 7.

Table 5. Academic performance by 5 th and 6 th graders.

\begin{tabular}{|c|c|c|c|c|c|c|c|c|}
\hline \multirow{2}{*}{$\begin{array}{l}\text { Question } \\
\text { number }\end{array}$} & \multicolumn{2}{|c|}{$\begin{array}{c}\text { Scholastic achievement rate of } \\
\text { the } 5^{\text {th }} \text { grader(Total 10/11 students) }\end{array}$} & \multicolumn{3}{|c|}{$\begin{array}{c}\text { Scholastic achievement rate of } \\
\text { the } \text { 6 }^{\text {th }} \text { grader(Total 9/11 students) }\end{array}$} \\
\cline { 2 - 10 } & Well & Somewhat & Not at all & $\mathbf{( \% )}$ & Well & Somewhat & Not at all & $(\%)$ \\
\hline 1 & 3 & 6 & 1 & $\mathbf{6 0 \%}$ & 4 & 2 & 3 & $\mathbf{5 6 \%}$ \\
\hline 2 & 3 & 7 & 0 & $\mathbf{6 5 \%}$ & 4 & 2 & 3 & $\mathbf{5 6 \%}$ \\
\hline 3 & 3 & 6 & 1 & $\mathbf{6 0 \%}$ & 5 & 1 & 3 & $\mathbf{6 1 \%}$ \\
\hline 4 & 3 & 6 & 1 & $\mathbf{6 0 \%}$ & 4 & 1 & 4 & $\mathbf{5 0 \%}$ \\
\hline 5 & 3 & 7 & 0 & $\mathbf{6 5 \%}$ & 6 & 0 & 3 & $\mathbf{6 7 \%}$ \\
\hline 6 & 2 & 7 & 1 & $\mathbf{5 5 \%}$ & 4 & 2 & 3 & $\mathbf{5 6 \%}$ \\
\hline 7 & 1 & 8 & 1 & $\mathbf{5 0 \%}$ & 7 & 1 & 1 & $\mathbf{8 3 \%}$ \\
\hline 8 & 2 & 7 & 1 & $\mathbf{5 5 \%}$ & 4 & 1 & 4 & $\mathbf{5 0 \%}$ \\
\hline 9 & 1 & 8 & 1 & $\mathbf{5 0 \%}$ & 4 & 2 & 3 & $\mathbf{5 6 \%}$ \\
\hline 10 & 1 & 8 & 1 & $\mathbf{5 0 \%}$ & 4 & 2 & 3 & $\mathbf{5 6 \%}$ \\
\hline 11 & 2 & 7 & 1 & $\mathbf{5 5 \%}$ & 4 & 1 & 4 & $\mathbf{5 0 \%}$ \\
\hline 12 & 2 & 7 & 1 & $\mathbf{5 5 \%}$ & 4 & 1 & 4 & $\mathbf{5 0 \%}$ \\
\hline 13 & 1 & 8 & 1 & $\mathbf{5 0 \%}$ & 4 & 2 & 3 & $\mathbf{5 6 \%}$ \\
\hline 14 & 1 & 8 & 1 & $\mathbf{5 0 \%}$ & 5 & 1 & 3 & $\mathbf{6 1 \%}$ \\
\hline 15 & 1 & 8 & 1 & $\mathbf{5 0 \%}$ & 5 & 1 & 3 & $\mathbf{6 1 \%}$ \\
\hline 16 & 2 & 7 & 1 & $\mathbf{5 5 \%}$ & 4 & 2 & 3 & $\mathbf{5 6 \%}$ \\
\hline 17 & 2 & 7 & 1 & $\mathbf{5 5 \%}$ & 4 & 2 & 3 & $\mathbf{5 6 \%}$ \\
\hline & \multicolumn{2}{|c|}{ Overall mean } & $\mathbf{5 5 \%}$ & \multicolumn{2}{|c|}{ Overall mean } & $\mathbf{5 8 \%}$ \\
\hline
\end{tabular}

In the $5^{\text {th }}$ grade of elementary school, the academic achievement rate was $55 \%$, and in the $6^{\text {th }}$ grade, the academic achievement rate was $58 \%$. In the case of $6^{\text {th }}$ graders, the distinction between 'well' and 'not at all' was more pronounced than in the $5^{\text {th }}$ grade. There is a $3 \%$ difference between the two groups, but it able to be seen the content we produced is something that even $5^{\text {th }}$ graders in elementary school can understand. Therefore, it is necessary to analyze the scholastic achievement rate after educating students lower than $5^{\text {th }}$ grade. The results of selfability assessment for each the boy and the girl groups among the $5^{\text {th }}$ grade respondents are shown in Table 8 .

Table 6. Academic performance according to gender in 5th grade.

\begin{tabular}{|c|c|c|c|c|c|c|c|c|}
\hline \multirow{2}{*}{$\begin{array}{c}\text { Question } \\
\text { number }\end{array}$} & \multicolumn{3}{|c|}{$\begin{array}{c}\text { Scholastic achievement rate of } \\
\mathbf{5}^{\text {th }} \text { grade male students } \\
\text { (Total 3/10 students) }\end{array}$} & \multicolumn{3}{|c|}{$\begin{array}{c}\text { Scholastic achievement rate of } \\
5^{\text {th }} \text { grade femalestudents } \\
\text { (Total 7/10 students) }\end{array}$} \\
\cline { 2 - 10 } & Well & Somewhat & Not at all & $\mathbf{( \% )}$ & Well & Somewhat & Not at all & $(\%)$ \\
\hline 1 & 2 & 1 & 0 & $\mathbf{8 3 \%}$ & 1 & 5 & 1 & $\mathbf{5 0 \%}$ \\
\hline 2 & 2 & 1 & 0 & $\mathbf{8 3 \%}$ & 1 & 6 & 0 & $\mathbf{5 7 \%}$ \\
\hline 3 & 2 & 1 & 0 & $\mathbf{8 3 \%}$ & 1 & 5 & 1 & $\mathbf{5 0 \%}$ \\
\hline 4 & 2 & 1 & 0 & $\mathbf{8 3 \%}$ & 1 & 5 & 1 & $\mathbf{5 0 \%}$ \\
\hline 5 & 2 & 1 & 0 & $\mathbf{8 3 \%}$ & 1 & 6 & 0 & $\mathbf{5 7 \%}$ \\
\hline 6 & 1 & 2 & 0 & $\mathbf{6 7 \%}$ & 1 & 5 & 1 & $\mathbf{5 0 \%}$ \\
\hline 7 & 0 & 3 & 0 & $\mathbf{5 0 \%}$ & 1 & 5 & 1 & $\mathbf{5 0 \%}$ \\
\hline 8 & 1 & 2 & 0 & $\mathbf{6 7 \%}$ & 1 & 5 & 1 & $\mathbf{5 0 \%}$ \\
\hline 9 & 0 & 3 & 0 & $\mathbf{5 0 \%}$ & 1 & 5 & 1 & $\mathbf{5 0 \%}$ \\
\hline 10 & 0 & 3 & 0 & $\mathbf{5 0 \%}$ & 1 & 5 & 1 & $\mathbf{5 0 \%}$ \\
\hline
\end{tabular}




\begin{tabular}{|l|l|l|l|l|l|l|l|l|}
\hline 11 & 1 & 2 & 0 & $\mathbf{6 7 \%}$ & 1 & 5 & 1 & $\mathbf{5 0 \%}$ \\
\hline 12 & 1 & 2 & 0 & $\mathbf{6 7 \%}$ & 1 & 5 & 1 & $\mathbf{5 0 \%}$ \\
\hline 13 & 0 & 3 & 0 & $\mathbf{5 0 \%}$ & 1 & 5 & 1 & $\mathbf{5 0 \%}$ \\
\hline 14 & 0 & 3 & 0 & $\mathbf{5 0 \%}$ & 1 & 5 & 1 & $\mathbf{5 0 \%}$ \\
\hline 15 & 0 & 3 & 0 & $\mathbf{5 0 \%}$ & 1 & 5 & 1 & $\mathbf{5 0 \%}$ \\
\hline 16 & 1 & 2 & 0 & $\mathbf{6 7 \%}$ & 1 & 5 & 1 & $\mathbf{5 0 \%}$ \\
\hline 17 & 1 & 2 & 0 & $\mathbf{6 7 \%}$ & 1 & 5 & 1 & $\mathbf{5 0 \%}$ \\
\hline \multicolumn{6}{|c|}{ overall mean } & $\mathbf{6 6 \%}$ & \multicolumn{3}{|c|}{ overall mean } & $\mathbf{5 1 \%}$ \\
\hline
\end{tabular}

For $5^{\text {th }}$ graders, boys' groups showed an average 15\% higher overall academic performance than girls' groups. However, there are not enough male student's samples, research on more students are needed. The results of selfability assessment for each the boy and the girl groups among the $6^{\text {th }}$ grade respondents are shown in Table 9.

Table 7. Academic performance according to gender in 6th grade.

\begin{tabular}{|c|c|c|c|c|c|c|c|c|}
\hline \multirow{2}{*}{$\begin{array}{c}\text { Question } \\
\text { number }\end{array}$} & \multicolumn{3}{|c|}{$\begin{array}{c}\text { Scholastic achievement rate of } \\
\mathbf{6}^{\text {h }} \text { grade male students } \\
\text { (Total 3/9 students) }\end{array}$} & \multicolumn{4}{|c|}{$\begin{array}{c}\text { Scholastic achievement rate of } \\
\mathbf{6}^{\text {th }} \text { grade female students } \\
\text { (Total 69students) }\end{array}$} \\
\cline { 2 - 9 } & Well & Somewhat & Not at all & $\mathbf{( \% )}$ & Well & Somewhat & Not at all & $(\%)$ \\
\hline 1 & 1 & 0 & 2 & $\mathbf{3 3 \%}$ & 3 & 2 & 1 & $\mathbf{6 7 \%}$ \\
\hline 2 & 1 & 0 & 2 & $\mathbf{3 3 \%}$ & 3 & 2 & 1 & $\mathbf{6 7 \%}$ \\
\hline 3 & 1 & 0 & 2 & $\mathbf{3 3 \%}$ & 4 & 1 & 1 & $\mathbf{7 5 \%}$ \\
\hline 4 & 1 & 0 & 2 & $\mathbf{3 3 \%}$ & 3 & 1 & 2 & $\mathbf{5 8 \%}$ \\
\hline 5 & 1 & 0 & 2 & $\mathbf{3 3 \%}$ & 5 & 0 & 1 & $\mathbf{8 3 \%}$ \\
\hline 6 & 1 & 0 & 2 & $\mathbf{3 3 \%}$ & 3 & 2 & 1 & $\mathbf{6 7 \%}$ \\
\hline 7 & 2 & 0 & 1 & $\mathbf{6 7 \%}$ & 5 & 1 & 0 & $\mathbf{9 2 \%}$ \\
\hline 8 & 1 & 0 & 2 & $\mathbf{3 3 \%}$ & 3 & 1 & 2 & $\mathbf{5 8 \%}$ \\
\hline 9 & 1 & 0 & 2 & $\mathbf{3 3 \%}$ & 3 & 2 & 1 & $\mathbf{6 7 \%}$ \\
\hline 10 & 1 & 0 & 2 & $\mathbf{3 3 \%}$ & 3 & 2 & 1 & $\mathbf{6 7 \%}$ \\
\hline 11 & 1 & 0 & 2 & $\mathbf{3 3 \%}$ & 3 & 1 & 2 & $\mathbf{5 8 \%}$ \\
\hline 12 & 1 & 0 & 2 & $\mathbf{3 3 \%}$ & 3 & 1 & 2 & $\mathbf{5 8 \%}$ \\
\hline 13 & 1 & 0 & 2 & $\mathbf{3 3 \%}$ & 3 & 2 & 1 & $\mathbf{6 7 \%}$ \\
\hline 14 & 1 & 0 & 2 & $\mathbf{3 3 \%}$ & 4 & 1 & 1 & $\mathbf{7 5 \%}$ \\
\hline 15 & 1 & 0 & 2 & $\mathbf{3 3 \%}$ & 4 & 1 & 1 & $\mathbf{7 5 \%}$ \\
\hline 16 & 1 & 0 & 2 & $\mathbf{3 3 \%}$ & 3 & 2 & 1 & $\mathbf{6 7 \%}$ \\
\hline 17 & 1 & 0 & 2 & $\mathbf{3 3 \%}$ & 3 & 2 & 1 & $\mathbf{6 7 \%}$ \\
\hline & \multicolumn{2}{|c|}{ Overall mean } & $\mathbf{3 5 \%}$ & & Overall mean & $\mathbf{6 9 \%}$ \\
\hline
\end{tabular}

In the case of $6^{\text {th }}$ graders in elementary school, the academic performance rate of the boy and girl groups differed somewhat. In the case of girl groups, the academic achievement rate was $69 \%$, the highest among all groups. there are also not enough male student's samples in this case, and research on more students are needed.

\section{Conclusion}

In this paper, we analyzed the elementary school curriculum currently in place to improve the creativity of elementary school students. Based on the analyzed data, we developed content for computer programming training. To improve computer programming skills using the content, for $5^{\text {th }}$ and $6^{\text {th }}$ graders in elementary school, students were taught for training on electronic circuits and parts related to Micro: bit \& RC Car for 12 hours and block coding classes to control them for 4 hours.

To check students' academic performance, two times surveys were conducted. The survey showed that there was the $55.73 \%$ improvement in academic performance compared to the previous class. Therefore, we could see that the $5^{\text {th }}$ grade of elementary school is content that is fully understandable. Also, the group with the highest achievement rate was the group of female students in the $6^{\text {th }}$ grade of elementary school.

\section{REFERENCES}

[1] Ministry of Science, ICT and Future Planning, "Mid-to long-term comprehensive measures of intelligence information society responding to the fourth industrial revolution," Intelligent Information Society Promotion Conference, 2017.

[2] J. Y. Kim, "Programming Education and Trends in Japan," Korea Education Forum, Vol. 286, pp. 33-37, 2017.

[3] J.S. Kim and S.K. Kwon, "A Study on Effective Software Learning Method for Elementary School Students," Conference on Multimedia Information Technology and Applications(MITA2019), pp. 383-384, 2019.

[4] M.J Lee, "With our country comparative analysis of different country education system," M.S. thesis, Inha University, 2008.

[5] Y.H. Sol, "Integration of Computers and the Internet Applied to Project-Based Learning in American Schools," CNU Journal of Educational Studies, Vol 37, No. 1, pp. 207-229, 2016.

[6] I. K. Yoon, Y. J. Jang, S. Y. Jeong, and W. G. Lee “An Analysis of the Difference of Perception on IT Convergence Learning after the Smart Device based Robot Programming Education According to Elementary Gifted Students' Level,' Journal of the Korea Society of Computer and Information, Vol. 20, No. 5, 2015

[7] O. Y. Kwon, K. S. Jang, and J. K. Min, "Curriculum Development of Computer Engineering based on NCS (National Competency Standards)," Journal of practical engineering education, 2015.

[8] J. D. Jang, and K. H. Joo, "Study of Problem-solving Ability for Elementary School Students based Study of Algorithm Learning Methods," Journal of the study on the culture of creative information, Vol. 1, No. 1, 2015. 
[9] S. S. Cho, "A Case Study of Course-Embedded Assessment for Program Outcomes in Computer Science \& Information Engineering", Journal of Internet Computing and Services(JICS), Vol. 17, No. 1, pp. 73-81, 2016

[10] J. Moreno-Leon and G. Robies, "Computer programming as an educational tool in the English classroom: a preliminary study," ResearchGate Conference, 2015. 03.

[11] J.R. Chris DiGiano, M. Koutlis, A.R. Jonathan Phillips, N. Jackiw, and D.Suthers, "Developing Educational Software Components," Computer IEEE, 1991.

[12] L.A. Johnson, Titus K.L. Schleyer, and D.M.D. "Developing High-Quality Educational Software," Journal of Dental Education Methodologies, Vol 67, 2003. 11.

[13] B. Isong, “A Methodology for Teaching Computer Programming: first year students' perspective," I.J. Modern Education and Computer Science, 2014. 09.

[14] Zacharis N. Z. "Measuring the Effects of Virtural Pair Programming in an Introductory Programming Java course, IEEE Transactions on Education, Vol. 54, No. 1, pp. 168-170, 2011

[15] Falkner N, Sooriamurthi R, and Michalewicz Z, "Puzzle-Based Learing for Engineering and Computer Science," Journal Computer, Vol. 43, Issue 4, pp. 2028, USA, 2010

[16] ProgeTiger Programme, http://www.hitsa.ee/iteducation/educational-programmes/progetiger, (201907-24, accessed)

[17] Minju Institute, The Present Status and Improvement Direction of Software Education, 2018.

\section{Authors}

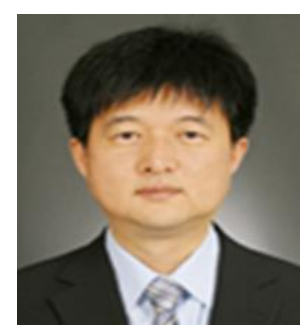

Jong-soo Kim He received his B.S. degree from Pukyong National University in 1992, his M.S. degree from the department of Computer Engineering, Busan University of Foreign Studies in 2003, and his Ph.D. degree from the department of Software Engineering, Dong-eui University in 2006. Since 2019, he is now a research professor in Software Convergence Center of Dong-eui University. His current research interests are in the software design and web applications.

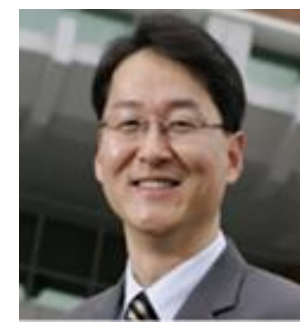

Soon-kak Kwon This author received the B.S. degree in Electronic Engineering from Kyungpook National University, in 1990, the M.S. and Ph.D. degrees in Electrical Engineering from Korea Advanced Institute of Science and Technology (KAIST), in 1992 and 1998, respectively. From 1998 to 2000, he was a team manager at Technology Appraisal
Center of Korea Technology Guarantee Fund. Since 2001, he has been a faculty member of Dong-eui University, where he is now a professor in the Department of Computer Software Engineering. From 2003 to 2004, he was a visiting professor of the Department of Electrical Engineering in the University of Texas at Arlington. From 2010 to 2011, he was an international visiting research associate in the School of Engineering and Advanced Technology in Massey University. Prof. Kwon received the awards, Leading Engineers of the World 2008 and Foremost Engineers of the World 2008, from IBC, and best papers from Korea Multimedia Society, respectively. His biographical profile has been included in the 2008 2014, 2017 2020 Editions of Marquis Who's Who in the World and the 2009/2010 Edition of IBC Outstanding 2000 Intellectuals of the 21st Century. His research interests are in the areas of image processing, video processing, and video transmission. 
Development of Contents for Effective Computer Programming Education in Curriculum of Elementary Schools 